\title{
ANTINOMIES OF KNOWLEDGE PRODUCTION AND SOCIAL SCIENCES DURING SOCIALISM
}

\author{
Guest Editors' Foreword
}

FLORIN POENARU ${ }^{1}$, NORBERT PETROVICI ${ }^{2}$

Andreas Glaeser (2011:XV) defined state socialism as an 'unacknowledged attempt to perform a revolutionary self-fulfilling prophecy'. For Glaeser, state socialism failed because its elites failed to produce adequate understandings of the everyday operations of socialism so as to device timely reforms of the system. In short, socialism came tumbling down because of an epistemic failure. Irrespective of the validity of Glaeser's conclusion it has the merit that it raises the point about the generation and certification of knowledge about the social life in socialism. How was this knowledge produced, by what means, to what ends, in which institutional settings and what mechanisms of feedback did it generate? This issue takes knowledge production during socialism and its instantiations in various institutional settings as its starting point and seeks to trace its antinomies.

The socialist state apparatus was a systematic producer of knowledge. The bureaucratic machine often employed the methods of the social sciences to gather and classify information, hypothesise contending interpretation, and suggest policy prescriptions. A vast array of activities benefited from the integration of these methods in the everyday state operations. Minute knowledge was needed in economic and spatial planning, or in demographical, educational, and health policies. Concurrently, the secret police also deployed observational techniques and made use of field notes that had a strong resemblance with those of the ethnographers.

At the same time, the social sciences per se produced a vast array of analysis of the very same society. During the four decades of socialism in Eastern Europe there were significant variations in the type, quantity, and quality of scientific literature produced. These variations were strongly interlinked with the state apparatus' needs for knowledge and societal projects. But the knowledge

\footnotetext{
${ }^{1}$ Central European University, e-mail: florinpoenaru@gmail.com.

2 Babeș-Bolyai University Cluj-Napoca, e-mail: norbertpetrovici@socasis.ubbcluj.ro.
} 
produced by the social sciences cannot be simply reduced to an appendix of the party-state logic and its projects, as it was by the anti-communist historians working in the totalitarian paradigm. A significant body of literature in sociology, economy, human geography, history, and demography was produced in particular institutional settings, intellectual networks and groups. and embedded in knowledge flows that transcended both the national boundaries and those imposed by the Cold War divisions. More often than not the knowledge produced by the social sciences came into conflict with the knowledge produced by the state or with the knowledge expected by the state. Rather than being a simple relation of subordination, the relationship between the socialist state, the social sciences, and the process of knowledge production was one of contention, friction and negotiation, therefore acquiring a particular history of its own within the broader political, economic and social dynamics of socialism.

This special issue seeks to investigate precisely this tension between state apparatuses, knowledge production, and the social sciences and the underlining political, ideological, and epistemic formations constitutive of this relationship. More specifically the contributions gathered here explore the institutional settings and the intellectual practices of knowledge production within the socialist social sciences and the policy practices of the state apparatuses and their intersection and collusion. Moreover, they point out how key socialist processes like industrialization, urbanization, agricultural production, central planning, trade and secret police surveillance were imagined, developed, implemented, and recalibrated at the intersection of state needs and social sciences expertise. The aim is to open up a field of reflection about the socialist knowledge production that is anchored in institutional settings and practices and always linked with the mechanics and dynamics of state apparatuses. The overall goal has been to have a better understanding of socialist social sciences, beyond current myths and stereotypes, and to properly place their significance within the developmentalist logic of socialism. At the very least we hope we managed to open this conversation and to point out the merits of further continuing it.

This quest for embedded knowledge is the key feature of the framework of this special issue. We sought to take knowledge production seriously but not to fetishize knowledge as such. Contributions link knowledge production, either by the state, or by the social sciences, to institutional settings, policies, and overall developmentalist plans of the regime.

Norbert Petrovici's text makes a double argument. On the one hand, socialist sociology has developed in relation to the socialist economic planning and was an outcome of imagining and institutionalizing the socialist development plan after 1947. Miron Constantinescu was a key figure in both processes, mobilizing and developing sociological concepts to be used in 
economic and urban planning almost two decades before the official institutionalization of socialist sociology. On the other hand, academic concepts, like the 'urban area', developed by Miron Constantinescu and Henri H. Stahl played an important role in actually shaping socialist urban policies, tying economic growth to sub-national levels and allowing planners to regulate the economy as a set of inter-connected production chains. This perspective does away with the standard narrative of socialist sociology as a by-product of socialist policies, strictly subordinated to political interests. Here sociological knowledge production appears to be both foundational and performative: at the root of socialist planning but also able to generate concepts which in turn enabled policies to be implemented.

In his text, Ștefan Bosomitu expands on the history of the institutionalization of sociology in relation to political dynamics by emphasizing the field dynamics that led to a particular articulation of the discipline in its official guise. That sociology was an object of political contention is clear, but the struggles around it were not confined to that. Politics of knowledge entered into play in order to define the nature of sociology and its subsequent institutional and practical configuration. At least three different strands of sociology were in competition over the legitimate nature of the discipline. Miron Constantinescu was interested to transform sociology in the key discipline for knowledge production over the socialist modernization: urbanization, industrialization, and mechanization of the agriculture. A 'new sociology' for a 'new social order'. A second school, led by Tudor Bugnariu, Henri H. Stahl and Traian Herseni, tried to renew the interwar monographical tradition and put it to work in the new social context. And a third vision imagined sociology as a 'sociology of the concrete' transformations, working in the confines of the official ideological predicaments. The first two agendas have fused together through the collaboration of Miron Constantinescu and Henri H. Stahl, both searching to capture the needs for social knowledge of the socialist state. Their endeavour was to put those needs in a sociological form and to entrust the research of these brave new world to the very state apparatus that was the agent of the transformations. The third agenda became institutionalized in the main academic centres offering both the chance for competition over disciplinary authority and a certain autonomous empiricism. The atheoretical empiricism was conductive for prestige squabbles between figures as Ion Drăgan or Constantin Nicuță, while giving the illusion that some stakes are at play in the sociological field - which obviously was not the case. However, the point was to give the sociology the autonomy to research the new society as a bureaucratic tool for recording the various social transformations. 
András Vigvári and Tamás Gerőcs broaden the discussion of sociological knowledge production by investigating the concept of 'peasant embourgeoisment' not only in relation to socialism - when the need to reform the countryside was germane for the regime - but to broader history stretching back to the $19^{\text {th }}$ century. They convincingly show how the development, mobilization, and subsequent rediscovery of sociological concepts is inherently linked to material transformations in periods of crisis and as such sociological knowledge cannot be separated from global historical processes and conjunctions. But this is not a simple matter of conceptual obduracy. The authors' argument is that this overlapping history of conceptual formation and historical processes has important policy effects. This bespeaks a wider tendency both before and after socialism in the region, that of deploying sociological concepts for policy purposes, thus linking once more state knowledge and social sciences.

Finally, Florin Poenaru's text also deals with the intersection between socialist knowledge production and science, but it does so by looking at an unorthodox avenue and in a rather speculative manner. Poenaru argues that the role fulfilled by the secret police (the Romanian Securitate) was not simply that of monitoring and repressing the population but also of generating knowledge about the socialist society for the benefit of the state. The secret police was thus an ample mechanism of knowledge production that accumulated in the vast archive this institution left behind. Of course, the type of knowledge this institution produced and its particular purposes in socialism is ambiguous and more research in this direction is needed. Such a perspective, however, was so far precluded, the author argues, by seeing the secret police archive as a source of knowledge not as a knowledge-form. What warrants such a perspective is a close look at what the secret police agents were actually doing: that is, at the manner in which they generated the knowledge about the socialist society. Their work was very similar to that of the anthropologists (colonial or in the later instantiations of the discipline), especially their penchant for fieldwork and writing - that is, doing ethnography. This perspective complicates the relationship between state knowledge and social sciences during socialism by pointing out to an institution that also had an ambiguous position within the regime itself. Theoretically close and subordinated to the interests of the party, the secret police officers were also very skilled and autonomous actors, aligned with the ideology of the party but also able to notice the contradictions of the regime at the grassroots level. Hence, they occupied an ambiguous position between party hierarchy and the technical intelligentsia (whom they were supposed to monitor closely), just as the knowledge produced by the Securitate sat uneasily between state knowledge and social sciences. 
Postcommunist anticommunism relegated socialist social sciences to a footnote of political history and ideological subordination. To put it simply, they were never taken seriously and their entire history was erased together with that of socialism as aberrations. Following developments in the sociology of socialist knowledge production (Glaeser, 2011; Lampland, 2016; Verdery, 2014) this issue sought to take socialist social sciences seriously and thus open a necessary discussion of the relationship between state, knowledge and science during socialism.

\section{REFERENCES}

Glaeser, A. (2011). Political Epistemics: The Secret Police, the Opposition, and the End of East German Socialism. Chicago: University of Chicago Press.

Lampland, M. (2016). The Value of Labor: The Science of Commodification in Hungary, 1920-1956. Chicago and London: The University of Chicago.

Verdery, K. (2014). Secrets and Truth: Ethnography in the Archive of Romania's Secret Police. Budapest and New York: CEU Press. 